\title{
«The Tragic Imbroglio of the Other and Others» Lévinas and the Question of Justice
}

\section{Bernardo $\mathrm{F}^{*}$}

Faculty of Letters, University of Coimbra, Portugal

*Corresponding author: Fernanda Bernardo, Associated Professor of Philosophy at Faculty of Letters of the University of Coimbra, Portugal, Email: fernandabern@gmail.com

\section{Research Article}

Volume 4 Issue 2

Received Date: May 03, 2021

Published Date: June 02, 2021

DOI: $10.23880 /$ phij-16000181

\section{Abstract}

The Levinasian concern with "l'ethicité de l'éthique" (Derrida) leads him to re-think it, in line with the Hebrew "kadosh", in terms of meta-ethics as a dual relationship and as "prima philosophia" - this paper seeks to show how, in the radicality of its meta-ontological register, such a meta-ethics, apart from making us think the joint genesis of subjectivity and unconditional responsibility, carries a new thought of justice and, consequently, a kind of new paradigm in order to re-think the instituted in general as well as «mondialization/globalization»: it is the complex problematics of the "third" (testis, terstis) that, with this title «The tragic imbroglio of the other and others» (M. Blanchot), is elucidated here with the main intention of highlighting the ambiguity of the term justice (justitia / jus) - and its implications in the field of Law/Right and Human Rights - in the scope of the thought and work of Emmanuel Lévinas.

Keywords: Lévinas; Responsability; Subjectivity; Other; Otherness; Ethics; Justice; «Third».

«Die Welt ist fort, ich muss dich tragen» Paul Celan, Atemwende/Renverse du souffle, p. 113

"Qu'ai-je à faire avec justice ?» E. Lévinas, Autrement qu'être, p. 200

«I don>t know if you admit this somewhat complex system that consists in judging according to the truth and to treat in love the one who was judged. The abolition of death penalty seems to me an essential thing for the coexistence of charity with justice. " E. Lévinas in F. Poirié, Emmanuel Lévinas. Qui êtes-vous ? p. 97. 


\section{Philosophy International Journal}

Let's start this paper about the Levinasian re-thinking of justice/law (jus) from the primacy of ethics - itself rethought in terms of meta-ethics - by advancing, in a kind of thesis, the hypothesis that there is no difference between the spectral meridian $^{1}$ of the poem according to Paul Celan ${ }^{2}$ - an atopic, atropological and acosmic meridian of the poem thought as a step beyond the human, the language and the world and as a salutation given to the other - and the meridian of ethics as «first philosophy» (prima philosophia) as re-thought by the French philosopher Emmanuel Lévinas - that is, in a metaontological, meta-gnoseological, meta-phenomenological and meta-theological register, in the line of the Hebrew "kadosh" (the separated), which deeply criticizes the philosophical tradition linked to the hegemony and the autocracy of the I/ Self, the theoretical and the knowledge, in terms of «relation to the other». A relation to the other man - to the other as human and the human as man, notice it since now - of a heteronymic-dissymmetric nature. A nature that draws the an-archie and the excellence of the scene without scene of a

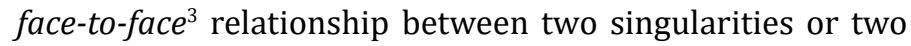
absolute unicities in which primacy is given to the other, to the nakedness of other's ${ }^{4}$ face (visage) - which is also the other as a face («panim») in his condition of absolute exteriority, or of absolute otherness ${ }^{5}$, as well as of first arrived [«premier venu»] .

The «nakedness of the face» - the symbol of the masterful height and, at the same time, of the spectrality or enigmaticity, vulnerability and ethical resistance ${ }^{6}$ of the other as other - is, in Lévinas' own words, «a pullout of the world context - of the world signifying as a context.» ${ }^{7}$ 《A pullout of the world context», an otherness, an exteriority, a salutation at the same time of farewell and of greeting the world - «Die Welt ist fort» / «The world is far away» - , which makes other's face and the asymmetrical relationship to it the new starting point, that is, the new meridian for re-thinking in new terms, in meta-ethical

1 «I find something that consoles-me a little for having done in your presence all this impossible path, this path of the impossible. I find the bond that, like the poem, leads to the encounter. [...] I find ... a meridian.», Paul Celan, «Le Méridien» in Le Méridien \& Autres Proses (Paris: Seuil, 2002), 84.

2 «I don't see any difference in principle between a handshake and a poem», Paul Celan, «Lettre à Hans Bender» in Le Méridien \& Autres Proses, op. cit., 44.

3 «The face to face remains the ultimate situation», Emmanuel Lévinas, Totalité et Infini, (Paris: Librairie Générale Française, 1998), 80.

4 «The way as the Other presents himself surpassing the idea of the Other in me, we call him, in fact, face», E. Lévinas, Totalité et Infini, op. cit., p. 43.

5 «The absolutely Other is the Other. [...] The other as the other is Other.», E. Lévinas, Totalité et Infini, op. cit., p. 28, 67.

6 Cf. E. Lévinas, Totalité et Infini, op. cit., p. 216-218.

7 E. Lévinas, « Un Dieu Homme ?» in Entre Nous (Paris : Grasset \& Fasquelle, 1991), 73. terms, the human, philosophy, the world and the con-living in the world - «ich muss dich tragen» / «I have to carry you»: that is, in order to rethink po-et(h)ically not only the human psyche in terms of unconditional responsibility, but also the world and its institutions. And po-et(h)ical or human is, for Lévinas, the world where one can judge its institutions and history itself ${ }^{8}$ - where, in its singularity or uniqueness, the human is the absolute exception to the world ${ }^{9}$, being so the measure of its justice (justitia).

Indeed, so thought - so, that is, in the sense of metaethics as an inter-human relationship -, ethics is also, like the poem for Celan, synonymous of the «human as human». Lévinas says it very explicitly, for example, in «Philosophie, Justice et Amour» (1982), while enunciating the singularity of his philosophical idiom of otherness, or of transcendence, and postulating the other (or, in metaphysical terms, the subject or the human person) as the absolute value, as the source of values ${ }^{10}$ and as the value of values and, as such, as the very principle of intelligibility and of the instituted and, so, also as the very principle to re-think in new terms globalization/«mundialization» - let us remember Lévinas's words:

«I describe ethics - it is the human as human. [...] The only absolute value is the human possibility of giving priority to the other. I do not believe that there is a humanity that can refuse this ideal, even if for that we have to declare it an ideal of sanctity. I do not say that man is a saint, I say that he is the one who understood that holiness was indisputable. It is the beginning of philosophy, it is the rational, it is the intelligible. ${ }^{11}$

And, in Sur Maurice Blanchot (1975), Lévinas, for whom alterity or «transcendence is alive in the relation to the other man $»^{12}$ as a face, even uses Celan's verse here in question «Die Welt ist fort, ich muss dich tragen» - «Le monde n'est plus, il faut que je te porte » - in order to postulate the other as the exteriority, the alterity or the absolute transcendence in relation to the world and, even, in relation to the transcendence of inter-subjectivity inherent to (personal) humanism: in its extreme vulnerability of mortal, the other

\footnotetext{
8 Cf. Lévinas E, « Le moi et la totalité » in Entre Nous, op. cit., p. 44.
}

9 Cf. Lévinas E, Totalité et Infini, op. cit., p. 24-30.

10 «It is a question of knowing whether others are as valuable as I am or whether others are a source of values. I lean before the second solution.», E. Lévinas, P. Ricoeur, «Entretien Lévinas - Ricoeur» in collective, Levinas. Philosophe et Pédagogue (Paris : ed. Nadir, 1998),13.

11 Lévinas E, Entre Nous, op. cit., p. 127.

12 Lévinas E, «Interdit de la représentation et "Droits de l'homme" in Altérité et Transcendance, op. cit., p. 129. 


\section{Philosophy International Journal}

is the only way out, «the only place where», in the world, «an outside [dehors] opens».

«Other - the only place where an outside [dehors] opens - has no way out: he sticks a knife in my flesh and a spirituality is found to plead itself guilty. Supporting the other, suffering in other, Celan's sublime word - "Le monde n'est plus, il faut que je te porte" - redounds in comedy in an asylum of alienated, where the sick have fun riding the narrator walking on four legs. The transcendence of the inter-subjective is oppression par excellence and altruism is stultifying: the "I" drowns out in its essence of horse. ${ }^{13}$

But, described that way, ethics is not only for Lévinas the un-condition of the human and a new «beginning for philosophy», for the rational and the intelligible: in the transcendence of its singular a-principality, of its an-archie, ethics is also, or it must also be, the very beginning, the (peculiar) «foundation», justification and measure of the instituted in general or, in Lévinas' own words in Autrement qu'être (1974), «the very origin of appearing, that is, the origin of the origin. ${ }^{14}$

Let us explain, trying to emphasize what we have for the uniqueness, that is, for the singularity of Levinasian philosophical thought in the context of the History of Philosophy ${ }^{15}$ : firstly, Lévinas' meta-ethical philosophical idiom questions very critically the egological ${ }^{16}$, the autonomic, the interested ${ }^{17}$ and totalitarian philosophicalcultural Westernity proposing the evasion from the being (1935), the exit of the weight and of the brutality of the being ${ }^{18}$, and the "autrement qu'être» (1974); and then, as if in a second moment, the philosopher rethinks the instituted - that is, the order of appearing, of phenomenality or of the symbolic - from the point of view of the meta-ethical inspiration, taken by the beginning of the intelligible, thus also emphasizing its performativity and its implications in the instituted field. Instituted that, according to the philosopher, should be derived or deduced from ethics thought in terms of dissymmetric relation to the other and as being the human as human. A human at last human - a human

13 Lévinas E, Sur Maurice Blanchot (Montpellier : Fata Morgana, 1975), p. 72.

14 Lévinas E, Autrement qu'être, op. cit., p. 204.

15 Cf. Fernanda Bernardo, Lévinas refém (Coimbra: Palimage, 2014).

16 « Philosophy is an egology [...] Ontology as the first philosophy is a philosophy of power.», Lévinas, Totalité et Infini, op. cit., p. 35, 37.

17 Lévinas E, «Être et Intéressement » in Autrement qu'être, op. cit., p. 4-6.

18 Let us remember the title of the 1935 work, De l'évasion, in which Lévinas proposes to «renew the old problem of being as a being» through the "evasion" of being, searching for the «ideal of happiness and human dignity that it promises. », Lévinas, De l'évasion (Montpellier: Fata Morgana, 1982),74. hetero-self-affected by the primacy and by the spectrality of the other in himself (but) outside himself. A human in substitution rethought in terms of unconditional hospitality ${ }^{19}$ and of «extravagant generosity» or responsibility ${ }^{20}$ by the other for or towards the other.

As Lévinas repeatedly proclaims, claiming the philosophical tradition - and not the religious one in the theological or onto-theological sense ${ }^{21}$ - of the inspiration of his thought: the Platonic tradition of Good beyond being or beyond essence (epekeinas tes ousias).

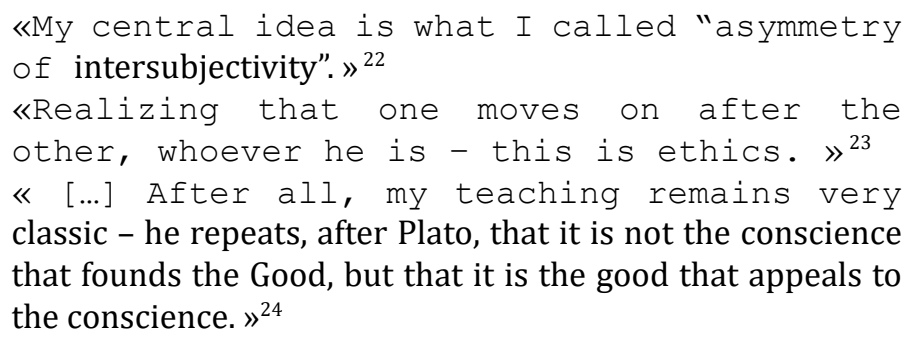
classic - he repeats, after Plato, that it is not the conscience that founds the Good, but that it is the good that appeals to the conscience. $»^{24}$

But, if the dissymmetric heteronomy is in fact the modality of the ethical relationship to draw with the expressive or, even, self-expressive ${ }^{25}$ nudity of the other man's face in his condition of absolute otherness and of «first arrived», and therefore in his condition of a new principle of intelligibility ${ }^{26}$, the truth is that in the world we do not live only in the face-toface interhuman order - humanity is multiple and we live in a world of citizens where the equality and the reciprocity of all before the law must be rigorous. Such is, as Maurice Blanchot has called it, «the tragic imbroglio of the other and others» an «imbroglio» to think both beyond our day-by-day litany of «everything is ethical» or «everything is political».

How do we combine, then, the insomnia of the heteronymic dissymmetry of the ethical order - main idea of Emmanuel Lévinas' philosophical idiom -, and therefore the inequality of principle of the "I/Self" under the injunction of

19 «Subjet is a guest.», E. Lévinas, Totalité et Infini, op. cit., p. 334. «Subjet is hostage», E. Lévinas, Autrement qu'être, op. cit., p. 142.

20 «The Self is Sub-jectum: he is under the weight of the universe responsible for everything.», E. Lévinas, Autrement qu'être, op. cit., p. 147.

21 In the onto-theological sense, because Lévinas also describes the ethical relationship as religious - religion and ethics, they both imply a dual relationship of face to face.

22 Lévinas E, Entre Nous, op. cit., p. 123.

23 Lévinas E, «La philosophie et la mort » in Altérité et Transcendance, op. cit., p. 170.

24 Lévinas E, « Dialogue sur le penser-à-l'autre » in Entre Nous, op. cit., p. 240.

25 Lévinas E, Totalité et Infini, op. cit., p. 43, 60-66.

26 Cf. Lévinas E, Transcendance et Intelligibilité (Genève : Labor \& Fidès, 1996), 28. 


\section{Philosophy International Journal}

other's face, with the equality and reciprocity of living in the world with others? In other words, how do we combine the elective ${ }^{27}$ unconditionality of the relationship of the "I" to the other with his relationship with all the others? How do we combine the incomparable uniqueness of the other and of the elected "I" with plurality, multiplicity and universality?

In short: how does the relationship to the other re-think, reinvent, inspire, restructure and supervise the inevitable, immediate and necessary, relationship with others? Which are the theoretical, social, legal and political implications and consequences that can be deduced from the primacy of ethics according to Emmanuel Lévinas, since, according to the philosopher, «The face to face announces, at the same time, a society and allows to keep a separate I [Moi] ${ }^{28}$ ? I underline.

It is precisely in the answer to these questions that the novelty - and the difficulty - of the singularity of Lévinas' ethical or meta-ethical thinking insinuates itself at the level of the instituted - and it insinuates itself revealing the consequences of the primacy of ethics in this level or, in the own words of the philosopher, revealing, on the one hand, that ethics is not a mere inconsequential abstraction and, on the other hand, how the instituted in general should be as if deduced or derived from the unshakeable primacy of ethics understood as a relation to the other - a relation to the face of the other. The multiplicity or the plurality - and so universality - should be re-thought as if deduced from the otherness and without saving it.

As Lévinas himself makes a point of remembering it in an interesting interview dated 1987, «Dialogue sur le penser-à-l'autre ${ }^{29}$, although proclaiming ethics' primacy, never he contested nevertheless the need for either the law or the political, but, as the philosopher also mentions in an important dialogue with P. Ricoeur - «Le bon plaisir de Paul Ricoeur» - , firstly, it is the uniqueness or the absolute singularity, and then, and only then, the collective or the universality: the social, the public or the collective should be, as if it were, deduced from the original sociability to personal unicity as well as it should be ethically justified, limited and evaluated by it. And without ever silencing or erasing it. Which is to say that, without giving in to «everything is ethics», Levinasian ethics is a carrier and instigator of a new thought for a kind

27 «The election replaces in me the notion of individuation. I say, for example, that there is incessant responsibility for an individuation of the self by election. I try to rehabilitate heteronomy while it can only mean slavery », E. Lévinas, Transcendance et Intelligibilité, op. cit., p. 43-44.

28 Lévinas E, Totalité et Infini, op. cit., p. 63.

29 «I never challenged the right or the political - I even tried to deduce its need - and I also showed its ethical limits », E. Lévinas, «Dialogue sur le penser-à-l'autre» in Entre Nous, op. cit., p. 239. of new paradigm of the social, the political and the legal, in a word, a kind of new paradigm to re-think the instituted. Or «mundialization»/globalization.

«[...] the dimensions of time [...] are caught up in the ethical relationship as I understand it, that is, as a relationship that covers uniqueness. And, consequently, everything that is collective comes after this first ethical relationship. $»^{30} \mathrm{I}$ underline.

It is the complex and crucial issue of the «third» (testis/ terstis) that bears the answer to these questions - it is this complex issue that comes into play here, revealing not only the singular impossibility - and, therefore, the ambiguity ${ }^{31}$, the contradiction (or, in Derrida lexicon, the aporia $^{32}$ ) that structures Levinas' ethics - , but also the immediate performativity and concreteness of Levinas' ethics: in fact, although firstly transcended, and therefore removed, the level of the onto-phenomenality of the world («The world is far»), as well as the level of the instituted in general (of theoretician, technician, socius, law (jus), politics, being and knowledge, etc....), enter immediately and permanently in scene in the midst of the duel of the ethical face-to-face - the scene of the singular welcoming of the uniqueness of the other - , since the «third one» immediately reveals himself in other's face, of whom he is in fact contemporary, dis-facing ${ }^{33}$ him.

But the «third» reveals himself immediately in the face of the other without, however, denying or destroying or appropriating the primacy of this one and of the ethical relationship to be drawn up with him - this primacy is unshakable. It always remains. There is no «third», because there is a multiplicity or a plurality - there is a multiplicity because the other has another other, because another other reveals himself immediately in other's face. As quite explicitly, in fact, Lévinas says it in the "Conclusions» of Totalité et Infini (1961) «The revelation of the third, inescapable in the face, is only produced through the face ${ }^{34}$ : which is to say that the other's face and the relationship of heteronymicdissymmetric nature - ethics itself or justice itself - to interweave with him and through which the «I» welcomes

\footnotetext{
30 Lévinas E, Ricoeur P, «Entretien Lévinas - Ricoeur » in coll., Levinas. Philosophe et Pédagogue, op. cit., p. 27.

31 Cf. Lévinas E, Autrement qu'être, op. cit., p. 206.

$32 C f$. Derrida J, « Le mot d'accueil » in Adieu, à Emmanuel Lévinas, op. cit. p. 60-62.

33 " The relationship with the third is an incessant correction of the asymmetry of proximity where the face is unraveled [où le visage se dévisage].», E. Lévinas, Autrement qu'être, op. cit., p. 201.

34 Lévinas E, Totalité et Infini, op. cit., p. 341.
} 


\section{Philosophy International Journal}

$\operatorname{him}^{35}$, responding to him and humanizing himself, remain priority. Irreducibly priority: it is the «third» who reveals himself in the "face of the other man", and not the other way around - but, as Derrida ${ }^{36}$ observes, the «third» does not wait either: his revelation is immediate, it is contemporary with that of the face. The «third» is always already present, since the epiphany of the face, in the face-to-face, thus affecting the very experience of the face in the face-to-face.

This is why, for Lévinas, the dissymmetry of the relationship to the other, as a face or as a neighbor, must give meaning to all other relationships to be established with others - this relationship is the significance or the signification of signification that is at the very origin of what, in Autrement qu'être (1974), the philosopher designates the «latent birth» of the order, of appearing, of logos, of consciousness, of being and of knowledge. A «latent birth» by which the «I» or the subject $^{37}$ passes from its condition of being extra-ordinarily ${ }^{38}$ obliged (but without bondage) to respond before the other to the other to his condition of questioner and of calculator - the «illéité» of the «third» (which Lévinas distinguishes from the «illéité» of the infinite ${ }^{39}$ ) bears with it the «birth of the question», of the first question, in the ethical responsibility itself, thus carrying, therefore, also the limit of the hyperbole of the (ethical) responsibility itself as the structure of (ethical) subjectivity, since Lévinas proposes and teaches us the joint genesis of subjectivity and of responsibility: an anarchic, infinite, hyperbolic and paradoxical or aporetic responsibility that shapes the «here am I» [«me voici»] given to the injunction of the other's face.

«My relationship with the other as a neighbor», says Lévinas in Autrement qu'être, "gives meaning to my relationship with all the others. All human

35 «The moral conscience welcomes others. It is the revelation of a resistance to my powers, which does not put them, as a force majeure, in question, but which calls into question the naïve right of my powers, my glorious spontaneity of living.», ibid., p. 83.

$36 C f$. Derrida J, « Le mot d'accueil » in Adieu, à Emmanuel Lévinas, op. cit., p. 66.

37 «Signification as proximity is thus the subjectss latent birth. Latent birth, because it falls short of the origin, short of the initiative, short of a designable and assumable gift, even if only by memory: anachronistic birth, prior to its own present, non-beginning, anarchy; latent birth, - never presence [...] Latent birth of the subject in an obligation without contracted engagement », E. Lévinas, Autrement qu'être, op. cit., p. 178.

38 «Thank you to answer is no small feat! [...] This is not the formality of any judicial interrogation supported by law enforcement. There is here an extra-ordinary obedience - service without servitude - to the straightness of the face of the other man whose imperative cannot fail to come from the threat and from whom the incomparable authority commands through suffering ... Response to this obligation. It is never exhaustive and it never removes liability. », E. Lévinas, Altérité et Transcendance, op. cit., p. 62.

39 Cf. Lévinas E, Autrement qu'être, op. cit., p. 191. relationships as human proceed from dis-inter-essement. The one-to-the-other of proximity [or of ethics or justice itself] is not a distorting abstraction. [...] The order, the appearing, the phenomenality, the being are produced in the signification in the proximity from the third. The appearance of the third is the origin of appearing, that is, the very origin of the origin. $»^{40}$

Let us note it: in the radicality of its archi-originarity and exteriority or transcendence, «the one-to-the-other of proximity», that is, of ethics or of justice, «is not a deforming abstraction», an inconsequential utopia, a mere soul supplement, a «huis-clos» - rather it is the meridian, that is, the new inspiring source to differently, poethically or justly, re-think the order of onto-phenomenality and, therefore, the so-called order of the symbolic and its institutions. From ethics emerges the possibility of the institutional, social and juridical-political, order - this one is both the limit and the possible concretization of the anarchie and of the excess of that one. As Autrement qu'être (1974) clearly will say, «the relationship with the third is an unceasing correction of the asymmetry of proximity. $»^{41}$ From proximity, that is to say, from the relationship to the other's otherness, because, for Lévinas, safeguarded, alterity becomes justly proximity - it becomes in-finite approximation.

In effect, the «illéité» or the «third» not only inscribes already the presence of society and of generality or universality in the ethical relationship itself, contradicting it and thus leading to knowledge, objectivity and justice / law (jus), as it allows to re-think in ethical terms this same society, since the Greeks, as Lévinas observes, founded on unity, on order, on immanence and on totality. On the other hand, while cheating itself, but in order not to be a mere insignificant «huis clos», ethics as a face-to-face relationship to the face of the other has to translate itself, to ex-write itself in the instituted, which is to say, has to be translated into the sphere of order or of ontophenomenality. Sphere of order that must be as if deduced from ethics relationship.

From the anarchic unconditionality of ethics or of ethical responsibility to the problem or to the questioning is, therefore, the way proposed by Lévinas to re-think the knowledge and the instituted in general in hetero-autonomic terms from the inspiration and from the attentive vigilance of the primacy of ethics thought in terms of relation to the other, proximity, meaning, justice, peace, desire, mercy ("rah'amim"), kindness, love without lust or Saying

40 Lévinas E, Autrement qu'être, op. cit., p. 202, 204.

41 Ibid., p. 201. 


\section{Philosophy International Journal}

(Dire $)^{42}$. Which is to say that, if, at first, Lévinas proposes an extremely critical exit from being ${ }^{43}$ - from the history or from the world - through ethics metaphysically rethought as a face-to-face relationship with the other, in a kind of a second moment - and we say in a kind of second moment, because, in truth, there is not exactly a second moment as such, since the «third» reveals itself immediately with the revelation and in the revelation of the face of the other or neighbor - the philosopher proposes the re-thinking of being, of knowledge and of the world from ethics' primacy. It is what, essentially, stamps his philosophical project. Autrement qu'être (1974) is very clear about this - it says:

«It is then necessary to follow in signification, in proximity or in Saying the latent birth of knowledge and of essence, [...] the latent birth of the question in responsibility. [...] It is necessary to follow the latent birth of knowledge in the proximity. [...]

If proximity did not order me but the other all alone, "there wouldn't have been no problem" - in any sense of the term, even the most general. The question would not arise, neither conscience nor self-conscience. Responsibility for the other is an immediacy previous to the question: precisely proximity. It is disturbed and becomes a problem from the moment the third enters. $»^{44}$

The immediate and permanent entry into the scene - let us note it - of the «third» within the ethical relationship itself is then the problem - this entry carries with it the start of the first question or of the first interrogation in the midst of a previous relationship of subjection and of obligation to respond to the other's injunction. And the first question in the order of the inter-human is the one that questions for justice/law: how to judge? What should the «I» do with justice? How to compare, calculate, weigh, judge? How? How does justice/law (jus) temper the audacity of the excess of the ethical relationship committed to think and to say «nobly the human» (Blanchot)?

Let us then look at the content of this disturbance brought about by the «third» entering the scene and let us start by asking - who is the «third» (testis, terstis), anyway? Where and when does he reveal himself? And with what kind of implications, with what consequences, that is, what is his role, his function in the economics of Levinasian ethics?

Lévinas answers these questions differently in Totalité et Infini (1961) and in Autrement qu'être (1974), the two

42 For this question, E. Levinas, Autrement qu'être, op. cit., § 3 «Le Dire et le Dit», p. 6-9.

43 Cf. Lévinas E, De l'evasion, op. cit.

44 Levinas E, Autrement qu'être, op. cit., p. 199-200. main works that are two fundamental milestones in the enunciation of his thought.

In Totalité et Infini (1961), the problem of the «third» is little more than stated in $\S 6$, «Autrui et les autres» of Chapter B of the 3rd Section entitled «Le visage et l'extériorité» - in effect, what is at issue in this 1961 work is, above all, the description of the ethical relationship, from the primacy granted to the infinite or to the ab-solute alterity, and its implication in the defense and in the weaving of ethical subjectivity ${ }^{45}$ : in counter-current not only of the tradition of the philosophy that is transmitted to us - which situates the human psyche «in knowledge and in conscience ${ }^{46}$ - , but also in counter-current of the dominant tendencies of the $60 \mathrm{~s}$, where the apocalyptic proclamation of the end of history, of philosophy, of man «or» of subject «was punctuated ( $c f$. Foucault ${ }^{47}$, in particular), Lévinas, in line with a certain Kierkegaard ${ }^{48}$ and a certain Rosenzweig ${ }^{49}$, insisted on the need and on the urgency to rethink the human beyond his fallacious and tragic sovereignty, aware as he was that «man is always beyond himself $»^{50}$ and is, therefore, always a question, always an enigma, always a «walk» towards himself (soi), «towards a new humanity» ${ }^{51}$.

Thus, to the first questions, Totalité et Infini (1961) answered ${ }^{52}$ saying that the «third» is the «whole world», it is «everyone», it is "the whole humanity», which immediately reveals itself in the face and with the face of the other man - «whole world» that, in the absence of any empiricity, is already revealed in the language itself, as the language itself - language that is the index of generality and of publicity - considered as a kind of first virus to heteroaffect the supposed purity of the intimate of the «us» or of the «between us». A language (Dit) to double by the gravity and by the generosity of the original ${ }^{53}$ or pre-original Saying

\footnotetext{
45 «This book presents itself, therefore, as a defense of subjectivity, but it will not apprehend it in terms of its purely selfish protest against the totality, nor in its anguish in the face of death, but as founded on the idea of the infinite.», E. Lévinas, Totalité et Infini, op. cit., p. 11.

46 Lévinas E, Altérité et Transcendance, op. cit., p. 11

47 «Let us remember, for example, the end of Les mots et les choses Paris: Gallimard, 1966), announcing the recent and precarious invention of man.

48 Cf. ELévinas E, Totalité et Infini, op. cit., p. 30, 341.

49 Let us remember the confession of the preface by Totalité et Infini: «The opposition to the idea of totality impressed us in Franz Rosenzweig's Stern der Erlosung, too often present in this book to be quoted.», ibid., p. 14.

50 Jean Wahl quoted by E. Lévinas in Hors Sujet (Montpellier: Fata Morgana, 1987), p. 120.

51 Lévinas E, À l'heure des nations, op. cit., p. 122.

52 Cf. above all E. Lévinas, « Autrui et les autres » in Totalité et Infini, op. cit., p. 233-236.

53 For the issue of language and the singular heterogeneity and inseparability between Dire (Saying)and Dit (Said) cf. E. Lévinas, Autrement qu'être, op. cit., cap. I, § 3, p. 6-9
} 


\section{Philosophy International Journal}

(Dire), that is, by the primacy of the addressing other to whom one speaks to: Autrement qu'être or au-delà de l'essence (1974) will say this Saying (Dire), that addresses itself to the other, the «avant-propos of languages» ${ }^{54}$. It is justly such a Saying (Dire) that will make Lévinas ${ }^{55}$ say that the essence of language is responsibility, hospitality, kindness, justice, ...

«Everything that happens here "between us" concerns everyone», says Emmanuel Lévinas, «the face that looks at him is placed in the middle of public order, even if I separate myself from him looking for having with the interlocutor the complicity of a private relationship and of a clandestinity. [...] The third looks at me in the eyes of the other [...] The epiphany of the face as a face opens up humanity. [...] The presence of the face - the infinity of the Other - is stripping, the presence of the third (that is to say, of all humanity that looks at us) and commandment that orders to order. [...] Every social relationship, as a derivative, goes back to the presentation of the Other to the Same, without any image or sign intermediary, solely by the expression of the face. The essence of society escapes, if one puts it as similar to the gender that unites similar individuals. [...] But the human community that is established by language - in which the interlocutors remain absolutely separate - does not constitute the unity of the gender. It is said as kinship of men. $»^{56}$

I underline: «Every social relationship, as a derivative, goes back to the presentation of the Other to the Same [...] ». And I underline in order to emphasize that, with regard to the role of the «third» in Totalité et Infini (1961), not only did Lévinas says that he interrupted the «between us» of the ethical faceto-face and that he derived the "social relationship» from the ethical reception of the face, as well as he also announced already the issue of "community» and of «human kind», rethought beyond the political and the biological, in terms of ethical «fraternity»: a «fraternity» that makes the «I» the other's guardian ${ }^{57}$. In turn, equality and reciprocity were then already also reconsidered based on an original inequality - the one drowned by the dissymmetric heteronomy of the duality of the ethical relationship between the «I» and the other held by the «experience par excellence» .

In short, the biological, as much as the social and the

\footnotetext{
54 Ibid., p. 6.

55 Cf. Lévinas E, «Texte du Traité "Yoma"» in Quatre Lectures Talmudiques, op. cit., p. 46.

56 Lévinas E, Totalité et Infini, op. cit., p. 334-235.

57 «Being responsible for other, being the guardian of other - contrary to the Caïnesque world view - defines fraternity.»,E. Lévinas, «La volonté du ciel et le pouvoir des hommes» in Nouvelles Lectures Talmudiques, op. cit., p. 20.
}

political already derived from the "original sociability» ${ }^{58}$ the one drowned by the ethical face-to-face between two absolute singulars or between two unique ones: «sociability» which, like Transcendance et Intelligibilité (1996) will state it, «as opposed to all knowledge and all immanence, it is the relationship with the other as such and not with the other as a pure part of the world. ${ }^{59}$

We know it already: the other, the other's face is not from the world, whose alterity is for Lévinas merely relative and formal ${ }^{60}$ - ab-solute alterity, the other is, in the world, a «black hole», an exception to the world and, as such, the condition of possibility for the re-thinking and for the ethical or just or humane experiencing of the world itself and its institutions. The world exists to give ethics a chance to exist ${ }^{61}$. As the philosopher will say it in «Paix et Proximité» (1984), hinting his «extravagant hypothesis» (Miguel Abensour ${ }^{62}$ dixit) in relation to the political and, in truth, in relation to the instituted in general, «it is the ethical order of human proximity that raises or that appeals to that of objectivity, truth and knowledge. ${ }^{63}$ In other words, ontology, kingdom and reign of inter-esse-ment in the course of philosophical-cultural Westernity, is no longer fundamental ${ }^{64}$ - it is rather the "ethical order of proximity» that, with its vocation of «holiness», supports the world and the instituted and calls for re-thinking the onto-phenomenality in general in new terms. In turn, although priority, the «ethical order of proximity» requires that of onto-phenomenality and that of the instituted, which re-thinks, founds, structures, justifies and attentively watches over. As Lévinas refers it in «Judaïsme et Kénose» (1985) :

«Being is through ethics and man. Man responds this way for the universe. He makes and undoes worlds, raises and lowers them. [...] The world is not because it perseveres in being, not because being would be its own reason for being, but because, through the human, it can be justified in its being. The human is the possibility of being-for-the-other -

\footnotetext{
58 «Sociabilité is this alterity of the face, of the for-the-other, that challenges me, a voice that rises in me before all verbal expression, in the mortality of the self, from the bottom of my weakness. This voice is an order », E. Lévinas, « La proximité de l'autre » in Altérité et Transcendance, op. cit., p. 113-114.

59 Lévinas E, Altérité et Transcendance, op. cit., p. 27.

60 For this issue, see E. Lévinas, Totalité et Infini, op. cit., p. 24-45.

61 Cf. Lévinas E, « Texte du Traité “Chabat” in Quatre Lectures Talmudiques, op. cit., p. 90

62 Cf. Miguel Abensour, « L'extravagante hypothèse » in Rue Descartes/19 Emmanuel Lévinas (Paris : PUF, 1998), p. 55

63 Lévinas E, « Paix et Proximité » in Altérité et Transcendance, op. cit., p. 148.

Lévinas E, Altérité et Transcendance, op. cit., p. 27.

64 Cf. Lévinas E, « L'ontologie est-elle fondamentale ?» in Entre Nous, op. cit., p. 13-24.
} 


\section{Philosophy International Journal}

this is the justification of all existing. The world is justified in its being by human des-inter-essement $»^{65}$

In turn, Autrement qu'être ou au-delà de l'essence (1974), the work in which the definitive maturity of Lévinas's thought is presented, focuses in more detail on the problem of the «third», advocating the need and the urgency to think about what the philosopher calls the «latent birth» of the question, knowledge, essence, saying, theme, law and politics, philosophy, conscience and self-awareness, in a word, the «latent birth» of knowledge and of the instituted, which had been as if suspended or withdrawn, in the intrigue of ethical responsibility, which both traces the relation of the «I» to the «other», to the primacy of the «other», as it draws the ethical uncondition of the «I» subject to the other, or hostage («otage») of the other, as a relation in «itself» (《soi») or as «subject-to-the-other» («pour-l'autre») : as the «anarchic one-to-theother from beyond being» ${ }^{66}$.

In this work of 1974, Lévinas not only clarifies in more precise terms who the "third» is, emphasizing the same dignity to that of the other (man) as a face or as a neighbor, but he also emphasizing the implications that he is a bearer, both in terms of their own ethical relationship and responsibility, whether in the field of the instituted, especially in the field of knowledge, social, juridical and political, which are of particular interest to us here.

In fact, the question of justice/law and the question of the political come into play with the immediate and permanent entry of the "third», operating both the limit of ethical responsibility and the interruption of the ethical relationship, thus leading to ambiguity and to contradiction ${ }^{67}$ of ethics itself in inscribing its anarchy and its excess in everything it transcends - everything, literally. But an everything now also already affected by the inspiration, the inscription (or rather, the ex-scription) of the primacy of ethical exceedance and transcendence - an everything that now accounts for the onto-phenomenality inspired ${ }^{6}$, hetero-affected, structured, and closely watched by meta-ethics. An onto-phenomenality that has now its «latent birth» in the primacy of ethics and that no longer translates and no longer testifies than the betrayal, hypocrisy ${ }^{69}$, contradiction and ambiguity of Levinasian ethics

65 Lévinas E, «Judaïsme et Kénose » in À l'heure des nations, op. cit., p. 145.

66 Cf. Lévinas, Autrement qu'être, op. cit., p. 199.

67 Cf. Lévinas, Autrement qu'être, op. cit., p. 8, 199, 206, 213, 218.

68 Let us remember that Lévinas thinks inspiration as «Other-in-Same, as Other instructing or awakening the Same - as the spirituality of the spirit», E. Lévinas, «La volonté du ciel et le pouvoir des hommes» in Nouvelles Lectures Talmudiques, op. cit., p. 36.

69 Cf. Lévinas, Autrement qu'être, op. cit., p. 233. itself, only possible as impossible as Derrida ${ }^{70}$ emphasized it.

Referring to the difficulties of enunciating ethics in its condition of meta-ethics, and thus referring to the difficulties of inscribing in the language (of Dit or as Dit) a «thought thinking beyond being» ${ }^{71}$, as it is a thought of otherness , of the infinite or of the absolute transcendence ${ }^{72}$, Lévinas highlights these difficulties in Autrement qu'être (1974) - not without at the same time also alerting to the risk of inoperability of ethics itself without this inscription in the language and, broadly, in the instituted. An instituted this way ethically rethought, founded, inspired, structured, justified and supervised.

«The contradiction that should compromise the meaning of beyond the being - which evidently is not - is inoperative without a second time, without the reflection about the condition of the statement that enunciates this meaning. In this reflection - that is, only after [«après coup»] - the contradiction appears: it does not explode between two simultaneous statements, but between the statement and its conditions as if they were at the same time. The statement of beyond the being [...] does not allow itself to be walled in the conditions of its statement - it benefits from an ambiguity or an enigma that is not the fact of an inattention, of a relaxation of thought, but of an extreme proximity to the neighbor, where the Infinite passes itself which does not enter as a theme in order to give itself there and thus deny its beyond. Its transcendence - more exterior exteriority, more another than all the exteriority of the being - doesn't passe itself if not by the subject who confesses or disputes it. Inversion of the order: the revelation is only made by the one who receives it, by the inspired subject whose inspiration the otherness in the same - is the subjectivity or the subject's psyche. [...]

It is necessary to follow the latent birth of knowledge in the proximity. Proximity can remain the signification of

70 Cf. Derrida J, « Le mot d'accueil » in Adieu, à Emmanuel Lévinas, op. cit., p. 66-68.

71 Levinas E, Autrement qu'être, op. cit., p. 199

72 "Awakened in the face of the other man, thought is not a thought of..., a representation, but beforehand a thought for..., a non-indifference for the other, [...] an awakening for the other man in his indiscernible uniqueness to know, an approximation of the first arrived in its proximity to the next and the only one. », E. Lévinas, «La proximité de l'autre» in Altérité et Transcendance, op. cit., p. 146.

Lévinas E, Altérité et Transcendance, op. cit., p. 27. 


\section{Philosophy International Journal}

knowledge itself where it shows itself. ${ }^{73}$

In the lexicon of Autrement qu'être (1974), proximity, that is, ethics or justice ${ }^{74}$ understood as a heteronymicdissymmetric relationship to the other as other, is, then, the fundament and the significance of all signification this, because it is precisely in the midst of this relation of significance, withdrawn from the mundane context, that the appearance of the «third» occurs: this immediately reveals himself in the face of the other-neighbor, of whom he is a contemporary. The contemporaneity of the multiple opens itself, however, in the diachrony of the ethical duality ${ }^{75}$.

Who is he? Who, then, is the «third», who reveals himself to be the bearer of the «latent birth» of knowledge and of the instituted in the proximity as the significance of signification? In other words, while it responds for the world and carries it, for, as $\AA$ l'heure des nations (1988) will remember, «the world is justified in its being by human disinteressement ${ }^{76}$.

«The third, 》 replies Lévinas in Autrement qu'être, «is other than the neighbor, but he is also another neighbor, but he is also a neighbor of the Other and not only his fellow man. What are then the other and the third for each other? $»^{77}$

With the same dignity of the other/neighbor in whose

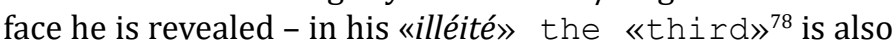
another other, that is, an «other/neighbor», a «face», an «absolute otherness» (ab-solus) -, the «third», as a witness (terstis), comes immediately to interrupt the duel of the ethical or of the just face-to-face with the uniqueness of the other. An interruption, an uninterrupted interruption that, however, does not annihilate the relationship, but exacerbates and infinitizes it.

It is precisely this interruption - that contradicts the idea of mediation of a hermeneutic type and that safeguards the separation of the terms in relation - that will lead Maurice Blanchot to designate it «relationship without relationship $»^{79}$ or «third gender relationship» ${ }^{80}$, in order to mean that such a relationship of uninterrupted interruption and separation

73 Lévinas E, Autrement qu'être, op. cit., p. 198-199, 200.

74 "We call justice this face approach, in the discourse.», E. Lévinas, Totalité et Infini, op. cit., p. 43.

75 Lévinas E, Autrement qu'être, op. cit., 203.

76 Lévinas E, À l'heure des nations, op. cit., p. 145.

77 Levinas E, Autrement qu'être, op. cit., p. 200.

78 «The third is also a neighbor, a face, an unattainable otherness.», E. Lévinas, «La proximité de l'autre» in Altérité et Transcendance, op. cit., p. 112.

79 «[... the relationship I have with the other does not go through being.», Maurice Blanchot, L'Entretien Infini (Paris : Gallimard, 1969), p. 84.

80 Ibid., p. 94-105. does not pass through the ontological, it really exceeds the ontological, and does not reduce the other to the same in the mode of vision, representation, knowledge, idea, image, concept or even understanding: the other remains other, absolutely other, and never the other of the «I» sovereignly autonomous, eager and hegemonic. Separation is the condition of the individuation and of the relationship - the condition of the interminability of the approximation relationship.

It is, in fact, this uninterrupted interruption of the ethical relationship that triggers its desire - and that also shapes the relationship as desire. As an insatiable (metaphysical) desire of the other ${ }^{81}$ or of the infinite, because, although the other is not infinite or the infinite, he is nevertheless infinitely other. It is, namely, in L'Entretien Infini (1969) that, in an admirable proximity to Emmanuel Lévinas, Blanchot explains the meaning of this relationship that he also predicts as «third gender» relationship - he says:

« - The unique dignity of the relationship that philosophy proposes to me to maintain with what would be unknown and that, in any case, escapes my power [...] is that it is a relationship such that neither I nor the other cease to be, in this same relationship, preserved of everything that would identify the other to me or confuse me with the other or alter us both in a middle term: it is an absolute relationship in the sense that the distance that separates us will not be reduced, but is, on the contrary, produced and absolutely maintained in this relationship.

- Strange relationship that consists of not having relationship.

- Which consists in persevering the terms in relation from what would alter them in this relationship, which then excludes ecstatic confusion [...], the mystical participation, but also appropriation, all forms of conquest, even this capture that, after all, it's always comprehension. $»^{82}$

Immediately interrupting the duel of the ethical or just face-to-face, the «third» comes then to introduce a CounterDiction in the Saying itself - in its condition of a word addressed to the other and of «avant-propos» of the language - claiming the need of comparison between the other and the «third»: «What then are the other and the third to each other? » asks Lévinas.

81 Cf. Lévinas E, Totalité et Infini, op. cit., p. 21-24.

82 Maurice Blanchot, L’Entretien Infini (Paris : Gallimard, 1969), p. 73. 
Need to compare the incomparable ones that both draw the limit of ethical responsibility, as the uncondition of the «I», and the advent of justice (as law) and, ipso facto, the emergence of the first violence in the ethical order: indeed, bearer of the «birth of the question » the " third » is also the bearer of the " birth of justice (law )» which, as Jacques Derrida ${ }^{83}$ rightly observes in « Le mot d'accueil »(1996), begins with perjury: violating the rectitude of the ethical desire voted to the unique and incomparable, the «third» points out the first perjury, which is then as originary as the ethical experience of the other man's face.

"What are they then, the other and the third, to each other? What did they do to each other? Which one passes before the other? », asks Lévinas in Autrement qu'être. «The other remains in a relationship with the third - of which I cannot answer entirely, even if I answer - before all the question only for my neighbor. The other and the third, my neighbors, contemporaries of each other, move me away from the other and from the third. [...] The third introduces a contradiction in the Saying [Dire], whose signification before the other went, until then, in a unique direction. It is, in itself, the limit of responsibility, the birth of the question: what do I have to do with justice? Matter of conscience. Justice is needed, that is to say, comparison, contemporaneity, reunion, order, thematization, $[\ldots] »^{84}$

And, almost in the same words of Autrement qu'être (1974), «Paix et Proximité» (1984) reiterates in the following terms the Levinasian description and implications of the "third» - the description of who he is, when and where he reveals himself and with what kind of implications and consequences both for ethics and for the instituted:

"The relationship with the other and with the unique one, which is peace, comes to demand a reason that thematizes and synchronizes and synthesizes, that thinks a world and reflects about being, necessary concepts for the peace of men.

Responsibility for the other man is undoubtedly, in its immediacy, prior to the whole question. But how does it obligate if a third disturbs this exteriority of two, where my subject subjection is subjection to the neighbor? The third is other than the neighbor, but he is also another neighbor and also an other's neighbor and not just his similar. What do I have to do? What have they already done to each other?

83 «The law would begin with such perjury - that it would betray ethical rectitude.», J. Derrida, «Le mot d'accueil» in Adieu, à Emmanuel Lévinas, op. cit., p. 67.

84 Lévinas E, Autrement qu'être, op. cit., p. 200.
Which one passes before the other in my responsibility? What are they then, the other and the third, one in relation to the other? Birth of the question.

The first question in the interhuman is question of justice. Henceforth it is necessary to know, to make up a cons-science. To my relationship with the unique one and the incomparable overlaps a comparation and, in view of equity or equality, a weight, a thought, a calculation, the comparison of the incomparable ones and, right away, a neutrality presence or representation - of the being, a thematization and the visibility of the face... $»^{85}$

I underline in the quote from Autrement qu'être (1974): «Justice is necessary, that is to say, comparison, contemporaneity, reunion, order, thematization ...», that is, in order not to fall into the "vertigo of ethical violence itself» ${ }^{86}$, and in order not to result in an innocuous abstraction, it is necessary, one must [commandment or ethical imperative!] to inscribe the ethical relationship of human proximity in the order of onto-phenomenality and of the instituted. And, ipso facto, it is necessary to re-think the instituted from justice and in the name of justice.

And I underline - «Justice is necessary» - in order to, in a kind of final synthesis, highlight two ideas implicated in this immediate appearance of the «third»: two ideas that are totally intertwined in each other and which I consider essential to emphasize the implications of the immediate disclosure of the «third» on the other/neighbor's face:

1. A first idea is, that, from the point of view of the subjectivity structure of the elected subject, this «latent birth» implies the passage from the immediacy of the answer and, therefore, from the unconditionality of responsibility to the question and comparison, because the «third's» «illéité» bears the «birth of the question» - indeed, and as we saw above, in the scene of the duality of the ethical relationship the «I» is unconditionally obliged to respond to the other, that is, it is obliged to «accuse himself», to say «yes», «here am I » [«me voici», «hineni»], to the other, to «his own» other, but, with the immediate entry of the "third one» (testis, terstis), also immediately enters in scene asking, calculating, comparing (the incomparable ones) and judging, the first question in the ethical interhuman order being the one that asks which of the two of the «I» of ethical duality, if the other if the "third», is the just one and, therefore, passes ahead

85 Lévinas E, « Paix et Proximité » in Altérité et Transcendance, op. cit., p. 148-149.

86 Derrida J, « Le mot d'accueil » in Adieu, à Emmanuel Lévinas, op. cit., p. 66. 
first.

As Lévinas points out in a dialogue with Paul Ricoeur - pointing out once again his disagreement with him and stressing the primacy of dissymmetry over reciprocity - , under the double injunction of the "other» and of the «third», the «I» has now to compare and to judge the two, in order to decide who is to him «the other par excellence» : the «I» must now compare and judge, it is true, but, let us also note it, he must compare and judge the incomparable ones, that is, without forgetting the uniqueness of them and the dissymmetric heteronomy of the relationship that links him to them in their status of $a b$-solute alterities:

«As for me», says Lévinas to a Paul Ricoeur committed to combining equality and solicitude ${ }^{87}$, «I say that dissymmetry precedes reciprocity. And, if one wants that in my relationship to the other, from the point of view of the human being, [...] there is priority for the other, then I have to be obliged in relation to him.

But I am not only with a single other, there is the third, there is the «he». In reality, the «he» has righter and, consequently, this initial situation, in which the right goes back to the right of the other, is complicated by the fact that there are men. Consequently, it is necessary that I know who my neighbor is, who is the other par excellence for me; it is necessary that I move from the state of my obligation in which the other is unique, is the person for whom I am responsible, for whom I have to answer and who is, therefore, unique, to the state in which I compare this unique one with others unique ones. ${ }^{88}$

And the philosopher adds further:

"For my part, I speak of a state of the human that precedes reciprocity and that becomes reciprocity precisely because there is a multiplicity of people and that, more than being voted to the other more than to myself, I am obliged to compare others, that is to say, I must reduce them to my knowledge and to myself. It is necessary that I know what

87 «Equality, whatever the module is, is for life in institutions what solicitude is for interpersonal relationships. The solicitude gives face to face with another that is a face, in the strong sense that Emmanuel Lévinas taught us to recognize him. Equality comes face-to-face with another person. In which the distributive character of "anyone" moves from the grammatical plane [...] to the ethical plane. So the sense of justice does not remove anything from solicitude; it assumes it, insofar as it considers people to be irreplaceable. On the other hand, justice adds to the concern, inasmuch as the field of application of equality is the whole of humanity.», P. Ricoeur, Soimême comme un autre (Paris: Seuil, 1990), p. 236.

88 Lévinas E, Ricoeur P, «Entretien Lévinas - Ricoeur » in colectivo, Levinas. Philosophe et Pédagogue, op. cit., p. 15. one is in relation to the other, that is, it is necessary that I am concerned with justice and that I enter into considerations about this need for justice on which research, objectivity and knowledge are established. Consequently, for me, epistemology stems from ethics. ${ }^{89}$

And it is precisely from this need to compare the unique and incomparable ones, and therefore from the need to pass from the obligation to answer to the obligation to $a s k$, to calculate and to judge, that elapses also, beyond the contradiction of ethics itself, the limit of the ethical responsibility, which Lévinas has for the un-condition $^{90}$ of the ethical or just or human subject: as Jacques Derrida points out in «Le mot d'accueil» (1996), responsibility immediately passes from ethical to ethicalpolitical-juridical (responsibility) ${ }^{91}$.

«That is the main idea», says Lévinas. «- I move from the order of responsibility, where even what does not concern me concerns me, from the order of mercy, to that of justice [justice/law] that limits this initial primacy of the other from where we started. $»^{92}$

«The third», says Lévinas, «he introduces a contradiction in the Saying [Dire], whose meaning before the other went, until then, in a unique direction. It is, in itself, the limit of responsibility, the birth of the question: what do I have to do with justice? Question of conscience. ${ }^{93}$

Let us note it: the limit of the ethical responsibility of the «I», elected (by the other, by the primacy of the other in his condition of «premier venu») by responsibility for responsibility, does not arise from the modality of the other's relationship with him: at this level, heteronymic dissymmetry, and its respective unconditionality, is the rule. As Lévinas often says, the other's responsibility for the «I» is from his strict responsibility, not from the one of this one. The limit of ethical responsibility is rather dictated by the modality of the relationship between the other and the «third one» - it is this modality that requires, from the part of the «I», the comparison (of the unique and incomparable ones) and the judgment. In «L'autre, utopie et justice», an important interview dating from 1988, Lévinas is very clear - he says:

89 Ibid., p. 16.

90 «Here, we try to say the subject's unconditionality, which does not have the status of a principle.», E. Lévinas, Autrement qu'être, op. cit., p. 147.

91 Cf. Derrida J, « Le mot d'accueil » in Adieu, à Emmanuel Lévinas, op. cit., p. 64.

92 Lévinas E, « La proximité de l'autre » in Altérité et Transcendance, op. cit., p. 113.

93 Levinas E, Autrement qu'être, op. cit., p. 200. 
Philosophy International Journal

«What I call responsibility for the other, or love without lust, the I cannot meet its demand but in himself; it is in his «here I am» of I, in his uninterchangeable unicity of elected. It is originally without reciprocity, which would run the risk of compromising its gratuitousness or its grace, or its unconditional charity. But the order of justice of the individuals responsible to each other arises, not to reestablish this reciprocity between the I and his other, but from the third who, next to the one who is other to me, is "yet another to $\left.\mathrm{me}^{\prime \prime}\right)^{94}$.

2. A second idea to underline is that, implying the translation or, more precisely, the ex-scription of the duality of ethics in multiplicity and universality, the «third one» is also the testimony of the performance of this ethical idiom in the order of the instituted: in effect, of the immediate and permanent revelation of the "third» in the face of the other man / neighbor, Lévinas deduces - 1.) the origin of the question - and, therefore, the origin of philosophy rethought no longer as " love of wisdom», but as " wisdom of love » - 2.) the origin of justice / law or right (jus): not the origin of ethical or unconditional justice ${ }^{95}$, of « justice that exceeds justice», but of justice / law or right - 3. ) and the origin of the political - the origin «of the social or political order of the City» ${ }^{96}$ which, for Lévinas, comes after the ethical order, as so vividly suggests the exclamation of the title «Politique après!» (1979) ${ }^{97}$. Also Autrement qu'être (1974) couldn't be more explicit in this regard - it says:

«Justice, society, the state and its institutions [...] nothing can escape the control of the responsibility of the one for the other. It is important to rediscover all these forms from the proximity [...]

Other's extra-ordinary commitment to the third calls for control, for investigation of justice, for society and for State, for comparison and for having, for thought and science, and for commerce and philosophy, and, outside anarchy, looking for a principle. Philosophy is this measure brought to the infinite of the being-to-the-other of proximity and as if the wisdom of love. ${ }^{98}$

And, almost in the same words, Lévinas reiterates it in «Paix et Proximité (1984), emphasizing what he calls the «latent birth» of the instituted (political, State, citizenship, law/right, socius, knowledge, philosophy, etc.) in the «extravagant generosity of the» ethical «to-the-other» - he

94 Lévinas E, « L'autre, utopie et justice » in Entre Nous, op. cit., p. 259.

95 Cf. Lévinas E, Quatre lectures talmudiques, op. cit., p. 40.

96 Lévinas E, Entre Nous, op. cit., p. 118.

97 Lévinas E, « Politique après !» in L'Au-delà du verset, op. cit., p. 221-228.

98 Levinas E, Autrement qu'être, op. cit., p. 202-203, 205. says there:

«Nothing could escape the control of the responsibility of the «one to the other» that draws the limit of the state and never ceases to appeal to the surveillance of people who would not be able to settle with the simple subsumption of cases under the general rule, that the computer is capable of.

It is not unimportant to know [...] whether the egalitarian and just State in which the European feels himself fulfilled - and that it is about to establish and, above all, to preserve proceeds from a war of all against all - or from the irreducible responsibility of one to the other, and if he can ignore the unicity of the face and of love. It is not unimportant to know it in order that the war does not make installation of a war with good conscience in the name of historical needs. Consciousness is born as the presence of the third in the proximity of the one to the other and it is, since then, as it proceeds from it that it can become des-inter-essement. The fundament of conscience is justice and not vice versa. Objectivity rests on justice. To the extravagant generosity of the to-the-other is overlaid a reasonable order, ancillary or angelic, of justice throughout knowledge, and philosophy is here a measure brought to the infinite of the being-to-theother of peace and of proximity and as if the wisdom of love. ${ }{ }^{99}$

Let us note it: the aforementioned disturbance brought about by the immediate appearance of the «third» gives an account of the implications and consequences of Levinasian ethics in the level of the instituted, thus showing that it is not a mere utopia or an inconsequential abstraction: indeed, everything - philosophy, society, justice / law, citizenship, politics, all instances that overshadow or disfigure the face and interrupt and complicate the duel of the ethical or just relationship - , everything must now be again re-thought as founded and justified in the responsible obligation in relation to the "extraordinary exteriority of the face» ${ }^{100}$ : such is Lévinas' «extravagant hypothesis» ( $c f$. Abensour) not only in relation to the political but, more broadly, in relation to the instituted in general. Everything comes from ethics, from peace or from justice - everything, literally! Everything should have its origin, foundation, justification and measure in an ethical or just or close relationship: in these terms, philosophy should be re-thought no longer as «love of wisdom», but as «wisdom of love»; justice / law should not be «just another legality governing human masses» ${ }^{101}$, but

99 Lévinas E, « Paix et Proximité » in Altérité et Transcendance, op. cit., p. 150 .

100 Cf. Lévinas E, « La proximité de l’autre » in Altérité et Transcendance, op. cit., p. 113.

101 Levinas E, Autrement qu'être, op. cit., p. 202. 


\section{Philosophy International Journal}

the incessant «remorse» for ethical justice, also called mercy, love without Eros, kindness or charity; and the State (and its institutions) should also no longer be Hobbes's Leviathan, nor should it be left to its administrative determinism, and should be dictated, justified and evaluated by the surveillance of ethical responsibility: thus, while everyone's war against all presides over the lupine principle ( $c f$. Hobbes) of the origin and justification of the State, the "extravagant generosity», which is the one of the responsibility of the subject-to-theother, embodies the "extravagant hypothesis» thought and proposed by Emmanuel Lévinas for the origin, justification and ethical measure of the State - «extravagant hypothesis» that appears to be Levinas' proposal for the promise of creating «on earth the conditions of political invention.» ${ }^{102}$ Proposal that also does not fail to configure the task that Lévinas gave to himself and bequeathed us - in his saying the «great task of enunciating in Greek the principles that Greece ignored. ${ }^{103}$ Principles that, in his eyes, came from the Bible, ethically read and interpreted, and consigned «the care for the foreigner, the widow and the orphan, the concern for the other man ${ }^{104}$ - which, in the disaffection of nationalism and of more or less folkloric particularism, nevertheless insinuates the exemplarism to which, despite the desired universalization, Lévinas votes Judaism ${ }^{105}$ (ethically interpreted and considered as a paradigm of humanity).

Recalling and saluting the ancestrally of a «spirituality of uncertain destiny» regarding the figure and the implications of the «third», Lévinas says it in «La Bible et les Grecs» (1986), in À l'heure des nations, suggesting that the promise of such a spirituality is indistinguishable from the promise of another humanity, another civilization and another Europe, which, in the philosopher's words, is nothing else but the Bible and the Greeks ${ }^{106}$.

«But, "first coming" for me and for the other, it would also be the third who joins us or who always accompanied us. The third is also my other, the third is also my neighbor. Who would be the first to speak? Where's the priority? It is needed a decision. Bible calls for justice and for deliberation! From the bosom of love, from the bosom of mercy. It is necessary and to judge

102 Lévinas E, « Politique après !» in À l'heure des nations, op. cit., p. 227.

103 Ibid., p. 233-234

104 Lévinas E, « Mépris de la Thora comme idolâtrie » in À l'heure des nations, op. cit., p. 74

105 While proclaiming «the ultimate value of the human message» that Judaïsm bequeathed to humanity, and not wanting to be a Jewish philosopher, but a philosopher and a Jew, Lévinas questions the existence of "A recognition of the Torah before Sinai?"», E. Lévinas, «Les nations et la présence d' Israel» (1987) in À l'heure des nations, op. cit., p. 112.

106 «What is Europe? It is the Bible and the Greeks.», E. Lévinas, «La Bible et les Grecs» in À l'heure des nations, op. cit., p. 155. and to conclude: it is necessary a knowledge, it is necessary to verify, objective science and system. It is necessary to judge, both the State and political bodies. It is necessary to bring back the only ones of love, external to all genders, to the community and to the world. It is necessary that we enter it ourselves. First violence in mercy. It is necessary, for the love of the unique, to renounce to the unique. It is necessary that the humanity of the Human be put back on the horizon of the Universal. Oh welcome messages from Greece! To instruct us in the Greeks and to learn their verb and wisdom. The Greek, inevitable discourse of Europe that the Bible itself recommends.

I call Greek [...] the way in which the universality of the West is expressed or endeavors to express itself, in all regions of the earth, surpassing the local particularities of the picturesque or the folk or the poetic or the religious. Language without prevention [...] Language that intends to translate - and always translate again - the Bible itself and that, in the justice that it allows to establish, it would not be able to forever obscure the uniqueness of the other, nor the mercy to which it appeals - even in the subject's heart-nor the responsibility for the other that only makes his teeth unravel in response to the word of God on the other man's face.

Souvenir of the Bible in the justice that conveys. Which, in concrete terms, means in Europe the incessant demand for justice behind justice, demand for an ever more just justice, more faithful to its original imperative in the face of the other. $»^{107}$

It is therefore not surprising that, underlying the hypothesis of the "extravagant" generosity "to the other"» 108 as the origin, justification and measure of the political, it is also gleaming the distinction between the human, in its irreplaceable uniqueness, the individual, selfish and egocratic under the banner of conatus essendi, and the citizen in his condition of a juridical-political subject thought from birth and from place - a distinction that calls for the rethinking of the city's statute (polis) and of citizenship itself from the uniqueness of the human and the primacy of its right of unique and incomparable, in order to shape it in new terms: in terms of human or ethical citizenship for an effective and just alter-globalist citizenship:

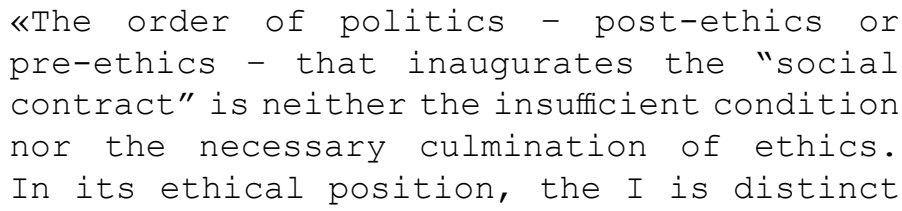

107 Ibid., p. 156-157.

108 Lévinas E, « De l’Unicité » in Entre Nous, op. cit., p. 216. 
both from the citizen, out of the City, and from the individual, who precedes all order in his natural selfishness, but from which political philosophy, since Hobbes, tries to take - or succeeds in taking - the social or political order of the City. $»^{109}$

And in «Dialogue sur le penser-à-l'autre» (1987), Lévinas reiterates, remembering that equality before the law, as a citizen's right, can never make us forget the initial inequality of the human that exists in all citizen or that all citizen is firstly also in himself - it is always necessary to rediscover the face of the unique under the comparison or after the judgment:

« [...] beings are not compare as faces, but already as citizens, as individuals, as a multiplicity in a genre and not as "unicity ones". » 110

In short, to the more or less apocalyptic proclamation of «politics after! », of Emmanuel Lévinas, corresponds the proclamation of «citizenship after! » A citizenship disconnected from the place (and) of birth - since it is precisely the bond of citizenship to birth and, therefore, to nationalism ( $c f$. Kelsen ${ }^{111}$ ), to blood and ground, which dictates the misfortunes of the figures of displaced populations, of stateless persons, refugees, exiles, foreigners, ... - , a citizenship disconnected from the place (and) of birth, we said, do not forgotten of the primacy of the human and founded and justified in the irreplaceable uniqueness of the human human, ethical or just.

Even so, vigilance proves to be the attitude of all instants to have towards the promise of a State «founded», animated, justified and limited by the «beyond of the State» ${ }^{112}$ : it is that Lévinas doesn't ignore also that the inter-human perspective, that the philosopher thinks and proposes as the foundation, justification, measure and limit of an ethical or just State, can always be lost or forgotten - alongside the weakness of democratic institutions themselves, violence of administration and of totalitarianism never leave to threaten the "political order of the City» ${ }^{113}$. Without a hint of irenicism,

109 Lévinas E, « La Souffrance Inutile » in Entre Nous, op. cit., p. 119.

110 Lévinas E, « Dialogue sur le penser-à-l'autre» in Entre Nous, op. cit., p. 241.

111 «Citizenship, or nationality, is a personal status whose acquisition and loss are governed by both state and international law. The state legal order makes this status the condition of a set of rights and obligations.», Hans Kelsen, Théorie Générale du Droit, II, II, C, d, p. 258.

112 Cf. Lévinas E, « Au-delà de l'État dans l'État » in Nouvelles Lectures Talmudiques (Paris : Minuit, 1996), p. 43 ss.

113 Lévinas E, « La Souffrance Inutile » in Entre Nous, op. cit., p. 119.
Lévinas reminds it, for example, in «Philosophie, Justice et Amour», confessing that one of the greatest disappointments of the history of the XX century was, for him, the fact that a movement like that of Marxism have fallen into Stalinism ${ }^{114}$ :

« [...] it is from the relationship with the face or from me in front of the other that one can talk about the legitimacy of the State or of its non-legitimacy. A State where the interpersonal relationship is impossible, where it is previously directed by the State's own determinism, is a totalitarian State. This way, there is a limit to the State. Whereas in Hobbes' view - in which the State does not leave from the limitation of charity but from the limitation of violence - limit cannot be fixed to the State.

[...] there is a possible agreement between ethics and the State. The just State will come out of the righteous and of the saints more than from propaganda and preaching. $»^{115}$

But what to understand here by a fair State? Also said by Lévinas «State of David» as opposed to the «State of Caesar» ${ }^{116}$ considered by the "place of corruption par excellence and, perhaps, [by] the last refuge of idolatry. $»^{117}$ ? A just or a messianic State is a liberal or a democratic State, answers Lévinas. A liberal State that has nothing, however, to do with the «neo-evangelical» naïveté of liberalism according to Francis Fukuyama, to whom such a State means the «end of history» and the access to the natural order of humanity.

In fact, if the violence of despotic arbitrariness, of nationalistic selfishness and of totalitarianism never fails to threaten the "political order of the City», and if, given to itself, this order can always result in an administrative determinism forgotten of the exceptionality of the human before and «beyond the State», the ethical, just or messianic State is broadly called by Emmanuel Lévinas «liberal State»it is a State that leaves room for the individual and that is able to put itself into question, a State

«always worried about his delay in relation to the demands of the face of the other. Liberal State - constitutive category of the State », explains Lévinas, «- and not a contingent empirical possibility; a State that admits beyond its institutions the legitimacy, be it trans-political, of the seeking

114 Cf. Lévinas E, « Philosophie, Justice et Amour » in Entre Nous, op. cit., p. 139.

115 Lévinas E, « Philosophie, Justice Cf. E. Lévinas, « L'État de Cesar et l'État de David » in L'au-delà du verset (Paris : Minuit, 1982), p. 209-220. Ibid., p. 216.

Lévinas E, « Dialogue sur le penser-à-l'autre» in Entre Nous, op. cit., p. 123, 139.

Levinas E, Autrement qu'être, op. cit., p. 202.

116 Cf. Lévinas E, «L'État de Cesar et l'État de David » in L'au-delà du verset (Paris : Minuit, 1982), p. 209-220.

117 Ibid., p. 216. 


\section{Philosophy International Journal}

and of the defending of Human Rights. State that extends itself beyond the State. Beyond justice, an imperative reminder of everything that, to its necessary rigors, must join coming from the human unicity in each of the citizens gathered in a nation, coming from non-deductible and irreducible resources to the generalities of a legislation. Charitable resources that will not have disappeared under the political structure of the institutions $»{ }^{118}$

And, as we have seen, bearer of the first question, the "third» is also the bearer of justice - not of ethical or unconditional justice, which Autrement qu'être will also designate as «justice that exceeds justice» ${ }^{119}$, but of justice/ right: the justice that Lévinas also designates «reasonable justice» that emerges as the perjury of ethical justice itself.

Let us explain, but not without emphasizing again that justice (law/right) comes, for Lévinas, not because of the limit of the ethical responsibility of the «I» by the other, for the other, and therefore not for the modality of the relationship of the other with the «I », but, rather, for the modality of the relationship between the other and the "third one » - it is the simultaneity of this relationship between the other, as a face, and the "third», which demands and dictates the comparison, the evaluation and the judgment. The reason why Lévinas insists on the fact that the comparison is a comparison of the incomparable or of the unique ones - an idea that reaffirms the supposition of the primacy of the ethical order and of the dissymmetric heteronomy that it draws:

«The I, precisely while being responsible to the other and to the third, cannot remain indifferent to their inter-actions and, in charity for one, he cannot get rid of his love for the other. The self [moi], the I [je] cannot stick to the incomparable uniqueness of each one, which the face of each one expresses. Behind the unique singularities, it is necessary to glimpse individuals of the gender, it is necessary to compare, to judge and to condemn them. Subtle ambiguity of individual and of unique, of personal and of absolute, of mask and of face. Here is the hour of unavoidable justice which, however, requires charity itself.

The hour of Justice, of comparing of the incomparable "gathering" themselves in species and human gender. And the hour of the institutions empowered to judge and the hour of the States in which the institutions are consolidated and the hour of the universal Law that is always the hard lex and the hour of the equal citizens before the law. $»^{120}$

118 Lévinas E, « Dialogue sur le penser-à-l’autre» in Entre Nous, op. cit., p. 123,139 .

119 Levinas E, Autrement qu'être, op. cit., p. 202.

120 Lévinas E, « L'Autre, Utopie et Justice » in Entre Nous, op. cit., p. 259.
One breathes, in fact, in the Levinasian work a certain terminological imprecision, and even an apparent ambiguity, regarding his thought of justice - in fact, Levinas uses the term justice to mean ethical justice (which the philosopher also equates to mercy, to love without concupiscence or without Eros, to kindness and to charity) as well as to mean justice as law or right: by justice-law/right one begins to understand the strict juridical legality, which «governs human masses and from which one removes a technique of "social balance" that puts antagonistic forces in harmony»" in order soon after to understand it as being the law inspired and harassed by justice itself; by ethical justice is understood the ethical or the meta-ethical register of justice that pure and simply equates it to the very ethics thought in terms of a dual relation to the other - to the other's face.

There is, in fact, in Lévinas's thought and work an equation of ethics - thought as an absolute relation to the absolutely other (as a face, or as a Master, or as You ( «Vous») ) - to justice ${ }^{122}$ : as such, justice is the recognition of the primacy of the right of the other, called the «first come» or the «first arrived» [«le premier venu»], and is therefore thought in terms of an absolute relation to the absolute or infinitely other. A one-way heteronymic-dissymmetric relationship, that is, a relationship of straightness that always goes in the sense of the «I» to the other - as a face or as a neighbor never proper, never domesticated, never appropriated - under the injunction of this one. So, Totalité et Infini (1961), for example, begins by defining justice in exactly the same terms as ethics - that is, as the mode of original access to the other man beyond ontology:

«We call justice», says Lévinas there, «this face approach, in the discourse. [...]

The establishment of this primacy of ethics, that is to say, of the relationship of man to man - signification, teaching and justice - primacy of an irreducible structure on which all others are supported [...] is one of the objectives of this work. [...]

The relationship with the other - that is, justice. [...]

Justice consists in recognizing my master in the other. Equality between people means nothing in itself. It has an economic sense and supposes money and already lays on justice - which, well ordered, begins by the other. It is the recognition of his privilege of other and of his magistracy, access to the other outside the rhetoric that is cunning, dominance and exploitation. ${ }^{123}$

121 Levinas E, Autrement qu'être, op. cit., p. 202.

122 See, for example, E. Lévinas, Totalité et Infini, op. cit., p. 89, 101, 274$277,330,332,337,338,340$.

123 Lévinas E, Totalité et Infini, op. cit., p. 67-69. 
This lack of distinction between ethics and justice at the time of Totalité et Infini (1961) is, moreover, recognized and corroborated by Lévinas himself in the important preface of January 1987 to the German translation of this work - on page II one can, in fact, read:

«There is, on the other hand, any terminological difference in Totalité et Infini between mercy or charity, the source of another's right passing before mine, on the one hand, and justice, on the other hand, in which the right of the other - but obtained after investigation and judgment - imposes itself before that of the third. The general ethical notion of justice is evoked in both situations indifferently.»

I stress. Alongside to its significant and terminological ambiguity, this same conception of (ethical) justice, distinct from law, also appears in Autrement qu'être (1974), above all in the rubric concerning the problematic of the «third one», under the name of «justice exceeding justice» [ «la justice passe la justice »] - it is about justice as recognition of the primacy of the other man's right and, ipso facto, as unconditional responsibility for the other's otherness, that is, it is about ethical justice that precedes, exceeds and follows, haunting, the justice (law/right).

This significant indistinction between ethics and justice begins by presupposing the important and necessary distinction without opposition between justice and law/right - a necessary distinction, albeit at the limit impossible as such, that underlies the uniqueness of Emmanuel Lévinas's ethical idiom: an idiom in which, as we have mentioned before, it is important in a first moment to point out its criticism of ontology, through its proposal of ethics as «prima philosophia» and as anarchic principle of intelligibility in general, and, as if in a second moment, it is important to highlight the Lévisian proposal of rethinking the order of the instituted from ethics, that is, as if deduced or derived from ethics. Likewise, carrying out a critique of legal ideology in the name of justice, it is in question to rethink, beyond to any schematism, a new juridical paradigm that implies a trans-national or trans-inter-national law linked to a new conception of both the law/right and the human subject.

As we have been emphasizing, from the primacy of the ethical or holiness order (holiness in the sense of separation), in which the primacy of the "other man» is recognized, that is, of the other as human and of the human as $\operatorname{man}^{124}$, must then be deduced or derived the order of «being» and of «appearing», that is, the order of «onto-phenomenality» and of the instituted. Instituted in which points

124 It is the (demanding) humanism as well as the androcentric hyperbole (cf. J. Derrida) that are thus envisaged in Levinasian ethics. out the political and the judicial that, above all, interest us here.

And the order of being and of appearing must then be deduced or derived in order that, in its singular an-archie, the ethical order itself does not fall into a mere abstraction. Hence the heterogeneity of principle between justice and law must then lead to a singular inseparability between justice and law and, therefore, to a new structure of both justice perjury $^{125}$ - and law/right - the remorse and the desire for in-finite perfectibility. And we say «singular inseparability» because never justice coincides with law - it never dissolves in it. The gap, and therefore heterogeneity and discontinuity, between justice and law/right always remains. It must, moreover, to remain.

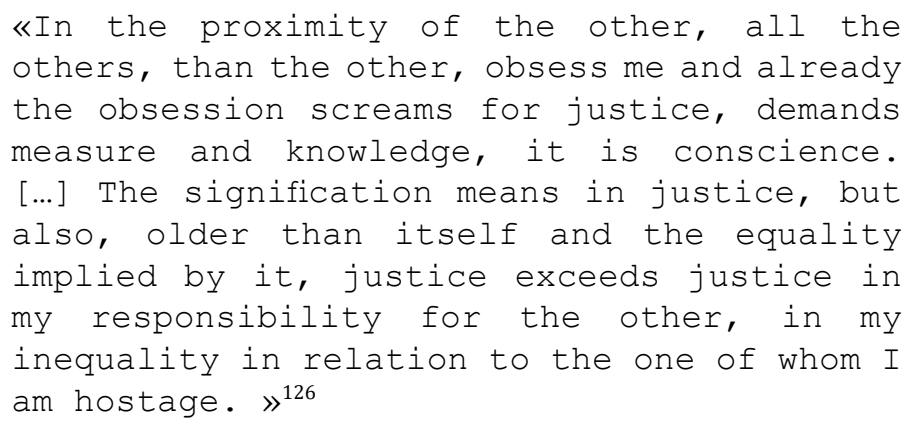

Let us note it: this important passage from Autrement qu'être (1974) does not only suggest the indistinction between ethics and justice in the thought and in the work of Emmanuel Lévinas - ethics and justice understood as recognition of the «sanctity» [«separation»] of the other man, and therefore as recognition of his primacy: beyond the assumption of both the distinction between justice and law/right and the need to translate and to implement ethical justice - the order of love without Eros, of mercy or charity - in justice / law, in the words of «L'autre, utopie et Justice» (1988) «the reasonable justice attached to dossiers» ${ }^{127}$, this passage from Autrement qu'être (1974) also suggests the need not only to base law or justice / law on ethical justice, but also the need to monitor and to evaluate justice / law from and in the name of ethical justice. It is, moreover, the resonance of this need that insinuates, on the one hand, under the indistinction between justice and ethics, on the other, in the terminological ambiguity of justice - such an ambiguity not only marks the distinction

125 «The terrible situation of two and three [...] i tis a condition of justice. If there is a justice it has to go through this terrible situation where there are two and three: I have a relation to the other in his/her singularity or uniqueness, anda the same time the third one is already in place.», J. Derrida, «Hospitality, Justice and Responsability» in Questioning Ethics, R. Kearney \& M. Dooley ed. (London \& New York: Routledge, 1999), p. 69.

126 Lévinas E, Autrement qu'être, op. cit., p. 201.

127 Lévinas E, « L'Autre, Utopie et Justice » in Entre Nous, op. cit., p. 260. 
without opposition between ethical justice and legal justice: rather, it suggests the realization of ethical justice in law/ right, suggesting ethical justice as the inspiration and the breathing of justice-law/right.

"In no way is justice a degradation of obsession, » says Lévinas, «a degeneracy of the to the other, a diminution, a limitation of anarchic responsibility, a "neutralization" of the glory of the Infinite, a degeneration that would take place as, for empirical reasons, the initial duo would become a trio. But the contemporaneity of the multiple takes place around the dia-chronicle of two: justice doesn't remain justice but in a society in which there is no distinction between near and far, but where the impossibility of passing by the nearest also remains; where the equality of all is conveyed by my inequality, by the excess of my duties over my rights. Self-forgetfulness moves justice. $»^{128}$

What does it imply that, in its indistinction of ethics in the sense of meta-ethics, ethical justice is the meridian, that is, it is the source that inspires, justifies and evaluates justice / law-right - not only does it come before the positivity of the legalism of law which, although better than pure arbitrariness, is nevertheless without love, without pity and without forgiveness ${ }^{129}$, as it also comes later, in order to temper the harshness of the law. As a maxim, Lévinas proclaims it very clearly in dialogue with François Poirié - he says:

«Justice [justice/law/right] is awakened by charity [ethical justice], but charity, which is before justice, is also after. »130

In short, that in its indistinctness of ethics and in its distinction, without opposition, from law/right, (ethical) justice comes before law, means that justice must dictate, found, inspire and animate law - that it also comes after it means that she must evaluate and judge him by dictating his remorse and his eagerness for increasing perfectibility. Remorse that brings with it the possibility of piety and forgiveness, that is, of mercy, which leads to the reunion and to the recognition of the irreplaceable uniqueness of the individual once judged and sentenced. Justice/law-right, in Lévinas's words the extraordinary legacy of Greece and the hour of the West, requires mercy or charity. This one is not, however, the «uncontrollable indulgence». As Lévinas explains it in dialogue with François Poirié and, afterword, in Nouvelles Lectures Talmudiques (1996):

128 Lévinas E, Autrement qu'être, op. cit., p. 203.

129 Cf. Lévinas E, «Les nations et la présence d'Israël » in À l'heure des nations, op. cit., p. 122

130 Lévinas E in Poirié F, Emmanuel Lévinas. Qui êtes-vous ? op. cit., p. 98.
"It matters to me that the other is recognized, but since the unique ones are multiplicity, calculations, comparisons are needed, which make the unique one disappears. It is necessary that I rediscover the unique one once the res judicata; each time again and each time as a living individual and a unique individual who can, in his own uniqueness, find what a general consideration cannot find. $»^{131}$

«Absolute justice would be done mercy, not in uncontrollable and unjust indulgence, but through the human court. $\gg^{132}$

And it is precisely in the re-encounter and in the «recognition of the unique», once judged in the light of the rigor of the law, that the insomnia of justice is revealed in its condition of recognition of the primacy of the right of the other over that of the «I» - insomnia of justice and remorse of the law that both reveal that ethical justice not only comes before the law, which inspires, grounds and structures it, but also comes after, reminding it the need to season the hard lex with the seal of love, of piety and of forgiveness. Remembrance that does not show only a criticism of pure legal determinism, or of the limits and insufficiencies of law - while revealing a criticism of the insufficiencies and limits of the law itself, such a reminder, beyond to show also the reason for the need of Humans Rights' existence, including in liberal and democratic societies, also reveals the urgency of the need of a critique of their own fundaments.

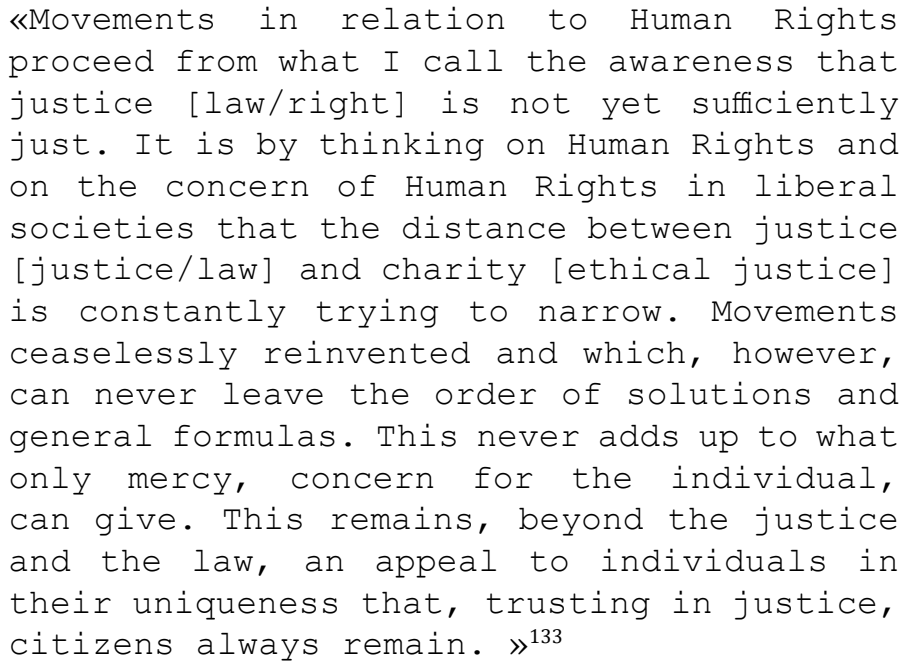

And «L'autre, utopie et justice» (1988) reiterates and states:

131 Ibid.

132 Lévinas E, «La volonté du ciel et le pouvoir des hommes » in Nouvelles Lectures Talmudiques, op. cit., p. 28.

133 Lévinas E in Poirié F, Emmanuel Lévinas. Qui êtes-vous ? op. cit., p. 98 
"It is in the name of the responsibility for the other, of mercy, of kindness to which the face of the other man appeals that the whole discourse of justice sets in motion, whatever the limitations and the rigors of the hard lex he will have brought to the infinite benevolence towards the other. Unforgettable infinity, rigors always sweetening. Justice to become ever wiser in the name, in remembrance of man's original kindness towards his other, in which, in an ethical disinteressement [...] the interested effort of the pure being, persevering in being, is interrupted. Justice always remaking against its own harshness.

Perhaps this is the very excellence of democracy, whose profound liberalism corresponds to the incessant deep remorse of justice: legislation that is always unfinished, always taken over, legislation open to the best. [...] Bad conscience of Justice! She knows that it is not as just as the goodness that arouses her is good. ${ }^{134}$

Beyond a criticism of the insufficiencies and limits of law, in the name of justice, that this not only holds the first word, but also always the last, also implies a criticism of the foundations of Human Rights themselves - a criticism of the foundation of law as well as a criticism of the foundation of the human being himself: Lévinas finds the ultimate source of law and of Human Rights in the primacy of the other man's right: a primacy that defines and characterizes justice, which, as we have seen, the philosopher equates to ethics as well as to mercy, to charity and to kindness:

«The right of man, absolutely and originally, does not make sense except in other as the right of the other man. Right in relation with which I am never quite satisfied with. » ${ }^{135}$

"That the Rights of man are originally the rights of the other man and that, beyond the unfolding of identities in their own identity and in their instinct for free conservation, they express the to-the-other of the social, the to-the-foreigner - this seems to me to be the sense of its novelty. ${ }^{136}$

And, although he did not carry out a systematic reflection on the theoretical foundations of death penalty - Jacques Derrida $^{137}$ was the only one to do so - , Lévinas sees in this

134 Lévinas E, « L'Autre, Utopie et Justice » in Entre Nous, op. cit., p. 259260

135 Lévinas E, «Interdit de la Représentation et "Droits de l'Homme" » in Altérité et Transcendance, op. cit., p. 135.

136 Lévinas E, « Les Droits de l'autre homme » (1989) in Altérité et Transcendance, op. cit., p. 155.

137 Derrida J, Séminaire La peine de mort, volume I (1999-2000) (Paris: distinction without opposition between ethical justice and justice/law or right, and then in this singular indisociability without fusion between justice and law, through which justice softens the rigors of law, the condition of possibility to advocate the unconditional and universal suppression of death penalty: the interdict of this is, for Lévinas, the index of a more humane, more just and merciful society:

« [...] the liberal state which, behind all the justice established as a regime, provides for a more just justice and also leaves a place for the individual and - alongside and after the respect for justice - for the resources of charity and of mercy of each one. Justice does not take it for definitive in a liberal State. We live in a society where a better justice would be needed. I don't know if you admit this somewhat complex system that consists in judging according to the truth and to treat in love the one who was judged. The abolition of death penalty seems to me an essential thing for the coexistence of charity with justice [justice/law]. ${ }^{138}$

This idea of the singular coexistence of ethical justice with justice/law - and singular coexistence due to the gap always existing between them, a sign that never ethical justice translates itself without rest into the present of justice/law, thus leaving this one always very much to wish and that one always on extreme alert and demanding - Lévinas reiterates it, in 1988, in an interview with the magazine Autrement ( $\mathrm{n}^{\mathrm{o}}$ 102), «L' autre, utopie et justice», suggesting once again that it implies the death penalty interdict:

"Justice and charity. This after-verdict, with its possibilities of mercy, still fully belongs - in its own right - to the work of justice. Should we then think that death penalty does not belong to the same title to the categories of justice? $»^{139}$

Perhaps, it is the need of this singular coexistence of ethical justice with justice/law that in his work Lévinas means with the terminological ambiguity or undecidability of the term justice - this singular coexistence does not just say the heterogeneity between ethics or justice and law, saying the primacy and the undesconstructibility of justice and the natural deconstruction of law: saying this heterogeneity, it also says the discontinuity that always exists between the ethical or just order and the legal and political order thanks to which, as Jacques Derrida points out,

\section{«[...] the political or legal content attributed}

Galilée, 2012; Séminaire La peine de mort, volume II (2000-2001) (Paris: Galilée, 2015)

138 Lévinas R in Poirié F, Emmanuel Lévinas. Qui êtes-vous ? op. cit., p. 97.

139 Lévinas E, « L'Autre, Utopie et Justice » in Entre Nous, op. cit., p. 261. 
remains in counterpart indeterminated, always to be determined beyond knowledge and beyond the entire presentation, the whole concept and all the possible intuition, singularly, in the word and in the responsibility taken by each one, in each situation, and from an analysis of each time unique - unique and infinite, unique but a priori exposed to substitution ${ }^{140}$

\section{References}

1. Abensour Miguel (2014) La communauté politique des "tous uns". Les Belles Lettres.

2. Abensour M (1998) L'extravagante hypothèse. In: Rue Descartes/19, Emmanuel Lévinas, PUF, fev, pp: 55-84.

3. Abensour M (1997) La démocratie contre l'État. Marx et le moment machiavélien. PUF.

4. Arendt Hannah (1984) Les origines du totalitarisme. L'impérialisme. Leiris M (Transl.), Fayard-Seuil.

5. Bernasconi R, Wood D (1988) The provocation of Levinas: Rethinking the Other. Routledge.

6. Bernardo F (2005) Para além do cosmopolitismo kantiano: Hospitalidade e "altermundialização" ou a Promessa da "nova Inter-nacional" democrática de Jacques Derrida. Revista Portuguesa de Filosofia, pp: 951-1005.

7. Bernardo F (2019) Derrida - o dom da différance. Palimage.

8. Bernardo F (2018) Derrida - toujours déjà "politique". Écriture - Parjure - Pardon. Revista Filosófica de Coimbra 27(54): 211-248.

9. Bernardo F (2019) L'inconditionnalité d'un acte de foi de Derrida dans l'à-venir. L'hospitalité, les humanités et L'université à venir. In: Colectivo Dons et Résistances. Études sur Jacques Derrida. Budapest: L'Harmattan Kiadó, pp: 201-226.

10. Bernardo F (2019) Uma voz de aliança por vir. Derrida e a paixão do outro/animal. Journal of Philosophy \& Science 21(1): 24-36.

11. Bernardo F (2014) A Desconstrução da Pena de Morte. Derrida incondicionalmente abolicionista in colectivo e.book Jacques Derrida. Lisboa: ed. Unyleya, col. Cultura, Media e Artes.

12. Celan P (1967) Renverse du souffle. Suhrkamp.

140 Derrida J, « Le mot d'accueil » in Àdieu, à Emmanuel Lévinas, op. cit., p. 199.
13. Cohen R (1986) Face to face with Levinas. State University of New York Press.

14. Jacques Derrida (1972) Marges, de la philosophie. Minuit.

15. Derrida J, Malabou C (1999) La Contre-Allée. Quinzaine Littéraire/Louis Vuitton 22(4) : 645.

16. Derrida J (1997) Manquements du droit à la justice. In: colectivo, Marx en Jeu. Descartes \& Cie, pp: 73-91.

17. Derrida J (1992) Points de suspension. Galilée.

18. Derrida J, Habermas J (2001) Le “concept" du 11 septembre. Galilée.

19. Derrida J (1993) Spectres de Marx. Galilée.

20. Derrida J (2003) Voyous. Galilée.

21. Derrida J (2018) Terreur et religion. Pour une politique à venir, Dialogue avec Richard Kearney. revue ITER, pp: 16.

22. Derrida J (2000) Foi et Savoir. Seuil.

23. Derrida J (1999) Une hospitalité à l'infini. Paroles d'aube.

24. Derrida J (2003) Força de lei, Fernanda Bernardo (Trans.), Campo das Letras.

25. Derrida J (2016) O Monolinguismo do outro ou a protese. Bernardo F (Trans.), Chão da Feira.

26. Derrida J (2005) Le souverain bien / O Soberano bem. Bernardo F(Trans.), Palimage.

27. Derrida J (1987) Adieu - à Emmanuel Lévinas. Galilée.

28. Derrida J (2017) Paroles Nocturnes. entretien com Alain Veinstein in L'entretien 03, Jacques Derrida. Seuil.

29. Derrida J (2008) Carneiros: o diálogo ininterrupto: entre dois infinitos, o poema. Palimage.

30. Derrida J, Stiegler B (1996) Échographies de la télévision. Galilée.

31. Derrida J (2018) Geschlecht III. Seuil.

32. Derrida J, Lacoue Labarthe Ph, Nancy JL (2017) Le dialogue de Strasbourg. in L'Entretien.

33. Derrida J (2012) Séminaire La Peine de Mort I. Galilée.

34. Derrida J (2015) Séminaire La Peine de Mort II. Galilée.

35. Derrida J, Marie-Louise M (2006) L'animal que donc je suis. Galilée. 
36. Derrida J (2010) La Bête et le Souverain, I. Galilée.

37. Derrida J (2010) La Bête et le Souverain, II. Galilée.

38. Derrida J (2002) Mondialisation: la guerre ou la paix ?. Divinatio. spring-summer 15.

39. Derrida J (2014) Carta à Europa. Fernanda Bernardo (Trans.). Revista Filosófica de Coimbra 46: 471-480.

40. Derrida J (2011) Politique et Amitié. Galilée, pp: 116.

41. Derrida J (2009) Demeure, Athènes. Galilée, pp: 58.

42. Derrida J, Ferraris M (2018) Le goût du secret. Hermann.

43. Derrida J (1980) La Carte Postale. Flammarion.

44. Derrida J (2004) La vérité blessante. in revue Europe, Jacques Derrida 901: 11-14.

45. Derrida J (2002) Fichus. Galilée.

46. Derrida J (2002) Inconditionnalité ou Souveraineté, ed. bilingue. Bitsoris V (Transl.), Patakis.

47. Derrida J (2003) Sauf le nom. Galilée, pp: 105.

48. Derrida J (1993) Khora. Galilée.

49. Derrida J (2001) Papier Machine. Galilée.

50. Derrida J (2013) Dar a morte. Fernanda Bernardo (Trans.), Palimage.

51. Derrida J (1996) Apories. Galilée.

52. Derrida J (1986) e P.-J. Labarrière, Altérités. Osiris.

53. Derrida J (2004) Une Europe de l'espoir. Le monde diplomatique.

54. Fukuyama F (1992) The end of history and the last man. The Free Press.

55. Heidegger (1979) Sein und Zeit. Max Niemeyer Verlag.

56. Kearney R, Dooley M (1999) Questioning Ethics. Contemporary Debates in Philosophy. Routledge.

57. Lévinas Emmanuel (1998) Totalité et Infini. Librairie Générale Française.

58. Lévinas E (1988) Totalidade e Infinito. Pinto Ribeiro J (Trans). Lisboa.

59. Lévinas E (1988) Autrement qu'être ou au-delà de l'essence. Kluwer Academic Publishers.

60. Lévinas E (1988) En découvrant l'existence avec Husserl et Heidegger. Vrin.

61. Lévinas E (1982) Éthique et infini. Fayard.

62. Lévinas E (1979) Le Temps et l'Autre. Quadrigue.

63. Lévinas E (1995) Altérité et Transcendance. Fata Morgana.

64. Lévinas E (1988) Difficile Liberté. Le livre de poche.

65. Lévinas E (1982) L’Au-delà du verset. Minuit.

66. Lévinas E (1968) Du sacré au saint. Minuit.

67. Lévinas E (1982) De l'évasion. Fata Morgana, pp: 99.

68. Lévinas E (1995) Les Imprévus de l'Histoire. Fata Morgana.

69. Lévinas E (1991) Entre Nous. Fasquelle \& Grasset.

70. Lévinas E (1977) Du Sacré au Saint. Minuit.

71. Lévinas E (1988) À l'heure des Nations. Minuit.

72. Lévinas E (1982) De Dieu qui vient à l'idée. Vrin 172(4): 681-682.

73. Lévinas E (1972) Humanisme de l'autre homme. Fata Morgana

74. Lévinas E (1996) Nouvelles Lectures Talmudiques. Minuit.

75. Lévinas E (2003) Deus, a Morte e o Tempo. Bernardo F (Trans.), Almedina.

76. Michael de Saint-Cheron (2006) Entretiens avec Emmanuel Lévinas (1992-1994). Pour une philosophie de la sainteté. Librairie Générale Française.

77. Marlène Zarader (1986) Heidegger et les paroles de l'origine. Vrin.

78. Lévinas E (1987) Emmanuel Lévinas. Qui êtes-vous ?. La Manufacture.

79. Lévinas E (1997) De la phénoménologie à l'éthique. revue Esprit.

80. Llewelyn John (1985) Beyond Metaphysics?: the hermeneutic circle in contemporary continental philosophy. Humanities Press International 17: 238.

81. Llewelyn John (2009) Margins of Religion. Between Kierkegaard and Derrida. Indiana University Press.

82. Mayor Federico, Jérôme Bindé (1999) Un monde 
nouveau. Odile Jacob.

83. Sallis John (1987) Deconstruction and Philosophy. Chicago University Press.

84. Zarka Yves Charles (2013) L'inappropriabilité de la terre. Armand Colin.
85. Zarka Yves Charles (2014) Refonder le cosmopolitisme. Presses Universitaires de France.

86. Henry David T (2009) La désobéissance civile. Le passager clandestin.

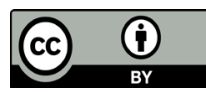

